\title{
Towards a Common Agricultural Data Space in the European Union: A Sustainable Development Perspective $^{*}$
}

\begin{abstract}
In February 2020 the European Commission announced a new strategy for data in which an innovative proposal to create a single European data space composed of many sectoral common data spaces, including the agriculture sector, was presented. It is expected that the common agricultural data space will provide support for delivering a smart, innovative and sustainable agri-food system from farm to fork. Based on the analysis of framework conditions for pooling and sharing agricultural data in the EU and the Commission's initiatives in this area, this article aims to discuss how and to what extent the common data space in agriculture could contribute to environmental, economic and social sustainability in the EU. It was concluded that the achievement of sustainability goals with the help of the planned common data space remains challenging, particularly in the context of rapid, but uneven pace of digital transformation in the agri-food sector in the EU. Overcoming legal, technical and other barriers to data sharing in the EU will not remove the fundamental problems of limited representativeness of current agricultural data assets in the EU. The design of the common data space in agriculture as well as the rules for data access and use should therefore be carefully considered. Also, specific and datarelated intervention measures, e.g. under the CAP, would be needed both to decrease the problem of a fragmented farm data landscape and to respond to the growing needs to collect and share private farm data that are highly relevant to achieving broader social goals and sustainability.
\end{abstract}

Keywords: European Data Strategy, common agricultural data space, agricultural data, digitalisation, sustainable development, sustainable agri-food system.

Katarzyna Kosior, PhD, Institute of Agricultural and Food Economics - National Research Institute, 20 Świętokrzyska St., 00-002 Warsaw, Poland, e-mail: katarzyna.kosior@ierigz.waw.pl, ORCID: 0000-0003-4825-730X.

* The Author would like to thank the two anonymous reviewers for their suggestions and comments. 


\section{Introduction}

The growing number of digital technologies, platforms and devices incessantly generating data pose new challenges and questions concerning how to store, exchange, share and use digital data assets for the benefit of individuals, economies and society as a whole. It is commonly agreed that data sharing and data analytics may support better decision-making in many domains. It is also stressed that new knowledge and insights hidden in aggregated data sets may help in scaling up innovations geared towards more intelligent and sustainable development pathways in current production and consumption systems. As radical changes towards sustainability are needed in many areas of economic and social life, and particularly in the domain of agriculture and food, the importance of suitable governance frameworks for collecting, sharing and using data cannot be emphasised enough (Posadas and Gilbert 2020). The absence of such frameworks may not only jeopardise the potential of the data revolution, but it may also create new imbalances. Data becomes an important economic asset that tends to be accumulated in the hands of digitally-savvy players interested in various monetisation strategies (Sadowski 2019). Vast amounts of data, including public data, are stored in isolated data silos that are hardly interoperable and accessible to potential external users. The use of data and the processes of sharing data across multiple platforms, sites and organisations are also surrounded by many security and privacy concerns. At the same time, it becomes clear that both public and private data have important social good functions that need to be taken into account while setting rules and standards for the emerging digital economy.

Since 2015, the European Commission has been implementing a series of measures and reforms designed to build a digital single market across members of the European Union. Recently, it also announced a new strategy for data with the proposal to create a single common data space based on European rules and values (European Commission 2020a). The EU regulations of 2016 and 2018 established the principle of the free flow of personal and non-personal data within the EU. Yet they have not removed many other barriers to data access and data portability. Nor have they solved a fundamental problem of limited trust when it comes to data sharing. Further actions are therefore being taken by the Commission both to increase data flows within and between member states and to boost data-driven innovation and competitiveness in the EU. The planned common data space aims to increase the EU pools of quality data available for use and re-use in different economic sectors and domains.

A common data space for agriculture is one of nine strategic sectoral data spaces foreseen in the EU data strategy. However, there is still no clear preference 
or vision with regard to what the planned data space should look like and how it should operate in practice. Different potential solutions and infrastructures are being considered. At the same time the EU institutions continue to work on data governance rules and standards to provide safe, efficient and trustworthy datasharing frameworks in the EU. The creation of a common European data space in agriculture seems particularly challenging. In many regards, the endeavour resembles the first historical attempts to establish a common market for agricultural products in the Community. Although the common space for agricultural data will be different from the common market for agricultural products, it will have similarly important and far-reaching consequences for farmers, agri-food businesses and consumers in the EU. Most importantly, with appropriate rules, standards and ecosystems in place it may help in delivering smart, innovative and sustainable food systems from farm to fork.

The aim of the article is to assess the potential role of the planned common agricultural data space in enabling the transformation towards an intelligent and sustainable agriculture and agri-food sector in the European Union. Intelligent development will be understood as the intensification of processes and operations that enhance all three pillars of sustainability - environmental, economic and social. The European Green Deal, with related strategies on biodiversity and the agrifood chain from farm to fork, and the post-2020 Common Agricultural Policy (CAP) have set new and ambitious goals for the sector. A significant part of the EU budgetary resources and investments are to be directed at supporting the digital and green transformation in agriculture, and specifically at actions aimed at achieving a new and better balance of nature, food systems and biodiversity. The COVID-19 pandemic has provided an additional impetus to accelerate efforts towards sustainability in the sector. It has also highlighted the importance of digital technologies as tools to make the sector more resilient and robust against potential future shocks and other adverse impacts. In this context the importance of the planned data space becomes even more evident.

To answer the question of whether, how and to what extent the common European data space in agriculture will be able to support a sustainable development pathway and green transformation in the EU agri-food sector, the article will examine the general conditions for pooling and sharing agricultural data in the $\mathrm{EU}$ and first conceptual views and ideas concerning the implementation and operation of the planned data space. The basic general conditions relate to the state of digitalisation processes in the agrifood sector in EU. The overview of these processes as well as the reference to major categories and types of agri-food data will help to better understand and assess the assortment and range of available data sources and hence potential data flows within the common market for data. The article will then discuss synergies and potential 
conflicts between digitalisation and sustainability in the context of the planned common data space in agriculture. The study is based on the analysis of publicly available data, documents, reports and research on digitalization and the use of databased technologies in the agri-food sector. The discussion concerning the potential contribution of the common agricultural data space to the achievement of sustainability goals is preceded by an overview of EU initiatives, documents and proposals for new regulations setting rules and standards for data governance and digital economy. Online presentations and information presented during various webinars organised by the EU institutions and other stakeholders have also been accessed to give a more complete picture of the planned common European data space in agriculture.

\section{Major Categories and Types of Agri-food Data}

Agricultural and agri-food sector data can be defined as the representation of facts, events, phenomena or situations in the agri-food sector and the food supply chain, starting from the representation of facts concerning inputs and raw materials, through the representation of primary production, processing, manufacturing, up to distribution, retail, and consumption. Stored or transmitted as qualified or quantified symbols, these representations map economic, social or environmental conditions, impacts and outcomes in the sector and in related areas, i.a. food supply and demand, input and output prices, farm incomes, land and labour productivity, farming techniques, soil health, the usage of chemical fertilisers, crop yields, animal feeding and production, ecosystem services at farm and landscape level, farm and agri-environmental subsidies, water consumption and energy use in food processing, food safety and quality, food nutritional values, consumer preferences, and many others.

The representation of the observations referred to above can be grouped into six major categories: farm data, enterprise data, market data, environmental and agri-environmental data, research, science and technology data and public policy data. Within each individual data category several different types of data streams may be differentiated (e.g. within the farm data category one can identify agronomic data, land data, farm management data, and machine data). Datasets collected and used in the sector therefore have different characteristics, sources, formats, dimensions and levels of granularity. They are also governed by different legal regimes, have different access rights, and different public and private values and functions. Yet harmonised data governance and the widest possible data sharing remains fundamental for providing meaningful insights and knowledge as how to support and drive innovative, sustainable and resilient food systems (cf. Jouanjean et al. 2020). 
Although there is no universal taxonomy covering all types of data, Nguyen and Paczos provided a useful framework that distinguishes data types based on: a) the funding for data generation or collection, b) ownership or data usage rights, c) data subject, d) methods of data generation and e) data source (Nguyen and Paczos 2020). Taking into account these classification criteria one can regroup agri-food data into public and private sector data, open (public domain) and proprietary data, personal and organisational data, user-created and machinegenerated data, and internal and external data. In other broader classifications non-personal data is also listed as an opposite category to personal data. It is worth noting that the EU legal framework builds on the distinction between personal and non-personal data. Non-personal data is considered to include data from automated industrial production processes, smart farming and other operations and devices connected to the Internet of Things. However, this data type still remains controversial, since with various data linkage and data mining techniques some non-personal data may quite easily be transformed into personal data.

When referring to different categories and types of agri-food data, one should also note that private and public sectors generate and collect data that in many respects complement each other. Access to public-domain data (open public data such as meteorological or spatial data) increases the value of private data sets concerning fields or crops for example. At the same time, private actors and businesses collect, own and control data that may be highly relevant for the public sector and the provision of public goods. It should be noted that some private sector data are already reported to public sector institutions and monitoring authorities (e.g. input data and parameters on land use and crop production as required by the CAP, the Nitrates Directive and other regulations). Yet with new devices and technologies, channelling the required information would be far more efficient. Additional and more detailed information concerning farming, food and ecosystems could also be obtained. These data streams are most often proprietary, which means they are protected by intellectual property rights or any other rights with a similar effect (e.g. database right or a trade secret). Nevertheless, many private sector data could still be potentially pooled with public-sector data (open data and certain categories of protected publicsector data) in a common agri-food data space as aggregated and anonymised or pseudo-anonymised datasets. However, data exchanges and data-sharing practices in the EU - both within the private sector and between the private and public sectors - still remain quite limited (Burg et al. 2020). Another important but somewhat neglected problem relates to the fact that the scope of private sector agri-food data continues to be constricted. The main sources of limitation in this area will be explained in more detail in the next section. 


\section{Digitalisation and Data Assets in the EU Agri-Food Sector}

The agri-food sector is still one of the least digitised sectors of the global economy. Moreover, there are significant differences between countries, regions and farms when it comes to the access, effective deployment and use of digital technologies. Although one can see that the sector is rapidly moving towards gradual digital transformation (IDSA 2021, p. 70), it should be also noted that there are clear digital frontrunners and many other groups and entities that lag behind (see Table 1). With current gaps in broadband access and coverage in rural areas, variegated farming systems and large number of actors involved in the food supply chain, transforming the agri-food sector through digitalisation is a quite complex and challenging task. Many actors lack financial capital, preparation and digital skills to embark on digital transformation. Farmers often do not have access to data collection technologies and they are unaware of potential improvements to be gained by using various technologies and types of data (Gossé et al. 2020, p. 35). Significant differences in returns on digital investments between upstream and downstream segments of the food supply chain also add to the complexity of the process.

As a result of uneven access to broadband services and data technologies, data assets in the agri-food sector tend to be more fragmented and at the same time more limited than in other economic sectors. This is particularly relevant for private farm data. Basically, the data value chain in agriculture is skewed towards conventional farming systems and large-scale mechanised farms. In northern regions of Europe (mainly in the Scandinavian countries and Britain) some farms had already started to apply data analysis and high-tech precision agricultural techniques in the 1990s (Pedersen and Lind 2017, pp. 5-12). The willingness to adopt new technologies and more advanced farming practices has generally been higher in regions where attempts to improve agricultural productivity were hampered because of poor soils and harsh and unfavourable climatic conditions. At the same time, faster adoption of precision agriculture technologies has been also seen in high income countries with well-developed agricultural sectors and high labour costs (the Netherlands, France, Germany, Austria). Obviously, farms in these countries now have richer experience and richer data sets than farms that are just beginning their digitalisation journey. Apart from different development paths, specific features and constraints of the emerging data economy also contribute to uneven representation of individual farming systems in the agricultural data value chain. Because of economies of scale, the market alone favours data from larger and more specialised farms. The focus of digital service providers on the needs of larger arable farms or farms with intensive rearing systems has also 


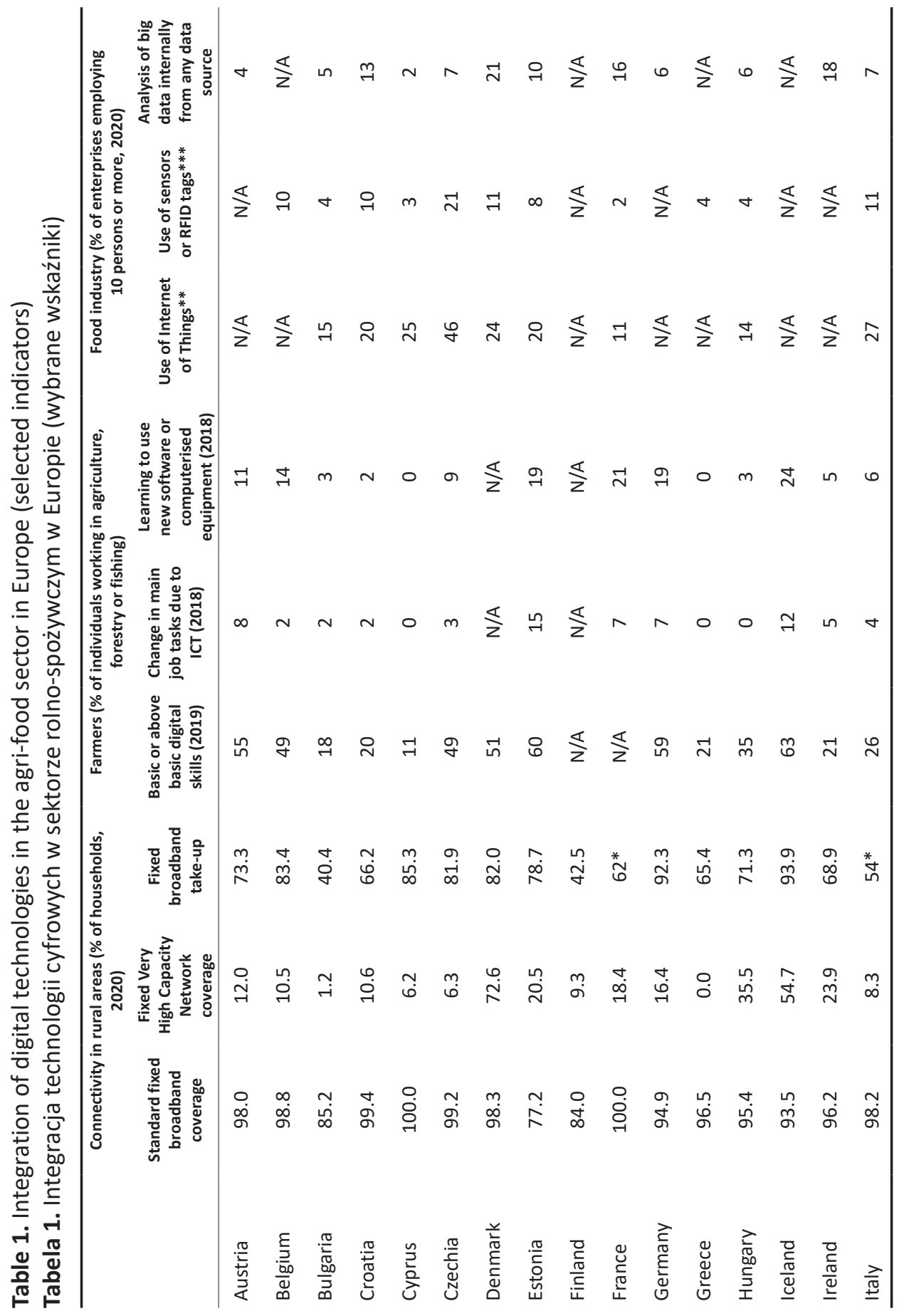




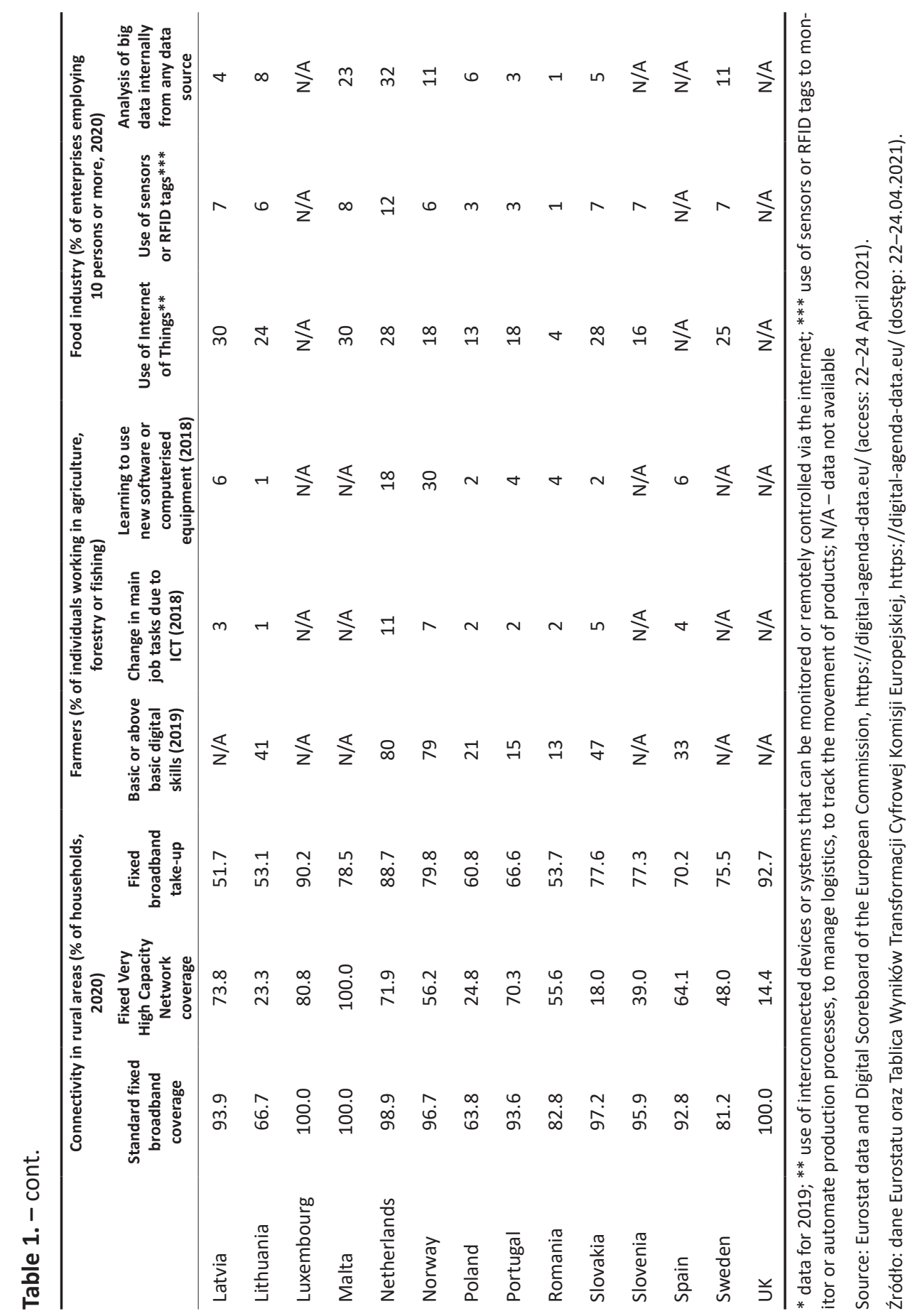




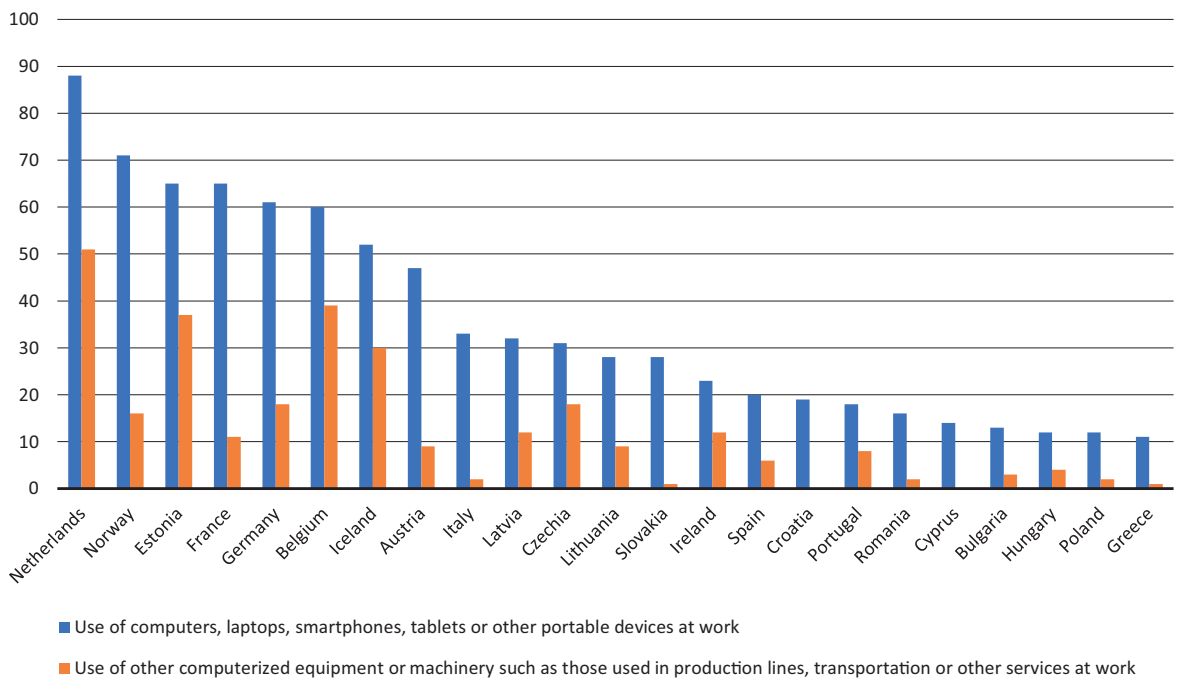

Figure 1. Farmers using ICT at work (\%) - member states of the EU and European Economic Area, 2018

Rysunek 1. Rolnicy wykorzystujący ICT w pracy (\%) - państwa członkowskie UE i Europejskiego Obszaru Gospodarczego, 2018

Source: Eurostat data [ISOC_IW_AP_custom_849813], EU/EEA member states for which there was no data available in the Eurostat as of 22 of April 2021 are not shown.

Źródło: dane Eurostatu [ISOC_IW_AP_custom_849813], państwa członkowskie UE/EOG, dla których dane nie były dostępne na dzień 22 kwietnia 2021 r., zostały pominięte w zestawieniu.

been driven by attempts to partly compensate for the high costs of fragmented data infrastructures. Moreover, larger units can provide access to more data points, which increases the accuracy of data models and subsequently the value of data tools offered on the market. These patterns create significant data disadvantages for many smaller and more diversified farms.

The fragmented character of agri-food data assets in Europe is also due to poor connectivity in rural areas and farmers' limited digital skills. Rural fixed broadband take-up (i.e. rural households with a fixed broadband subscription) is still lower by 12-30 percentage points compared to urban households (European Commission 2020 b, p. 20). There are also significant differences between individual countries in terms of rural fixed broadband coverage and use (Table 1). In addition, rural areas still have very limited access to high-speed connectivity required for the smooth operation of the Internet of Things, big data analytics, cloud computing and other advanced digital services based on real-time data. With uneven connectivity, patchy 


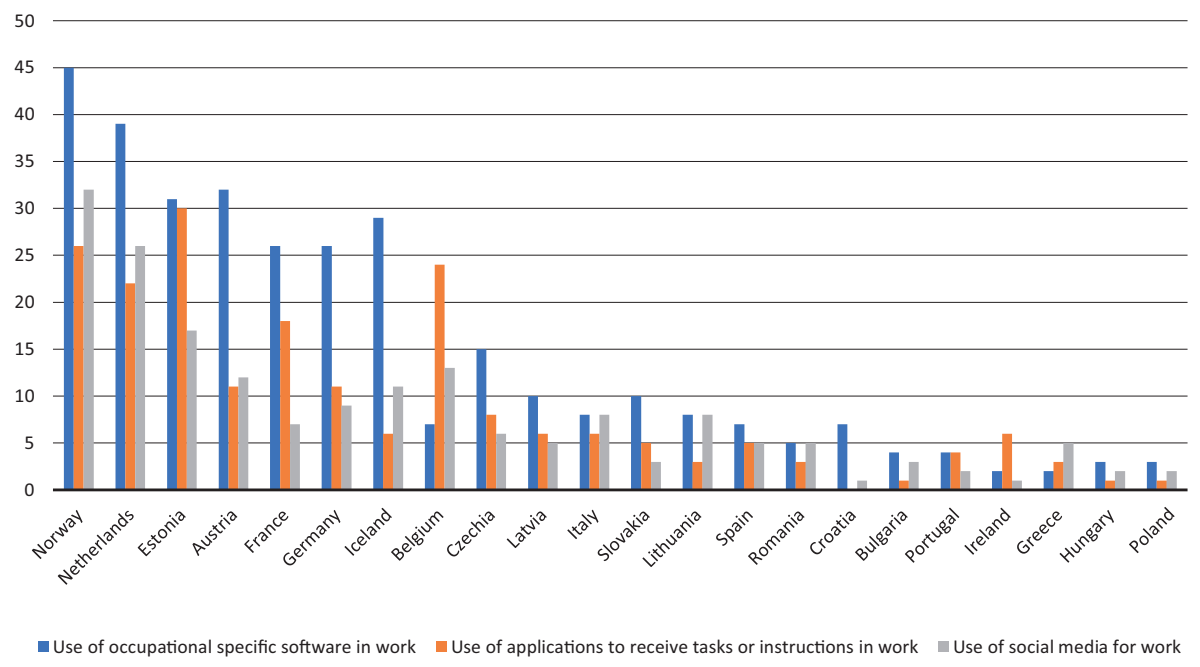

Figure 2. Farmers using occupational specific software, applications to receive tasks or instructions in their work and social media for work (\%) - member states of the EU and EEA, 2018

Rysunek 2. Rolnicy korzystający w pracy z oprogramowania specjalistycznego, aplikacji z zadaniami i instrukcjami oraz mediów społecznościowych (\%) - państwa członkowskie UE i EOG, 2018

Source: Eurostat data [ISOC_IW_AP_custom_849813].

Źródło: dane Eurostatu [ISOC_IW_AP__custom_849813].

digital literacy and other social and economic constraints, the number of farmers using digital technologies at work is highly differentiated in Europe. In 2018 almost $90 \%$ of the Dutch farmers used computers, laptops, smartphones, tablets or other portable devices at work, while in Greece, Hungary, and Poland only about 11-12\% of farmers supported their work with such tools (Figure 1).

Data generation is strictly related to the use of digital technologies. Hence the larger the number of farmers using ICT the larger the volume of agricultural data to be used to gain new insights and improve farming practices. The use of specific software and applications may also indicate that a farm is equipped with more advanced machines and sensors connected to the Internet of Things. These devices make it possible to collect more granular data concerning soils, crops, animals and other natural and farm resources. Current statistics on digitalisation in European agriculture suggests that most of such granular data may come from 
farms in only a few European countries, namely Norway, the Netherlands, Estonia, Austria, France, Germany and Iceland (Figure 2). Yet access to existing private agricultural datasets is also limited. Specifically, increasing global competition over data, a lack of data standards and interoperability issues have contributed to the concentration of data in a relatively small group of powerful market players that store, aggregate and analyse data for business purposes. The availability of data for use and re-use has been also hampered by the overall low levels of trust among farmers to data aggregators and data intermediaries (Burg, Wiseman and Krkeljas 2020; Wiseman et al. 2019).

Differences between countries in the use of more advanced digital technologies are generally less prominent in the downstream segments of the food supply chain. The Internet of Things, sensors and RFID tags are part of a technology bundle with robots and automated production lines, which are quite common in many food industry enterprises in Europe. Although the integration of digital technologies in the food industry is still relatively low when compared to other industries, it seems to be proceeding faster than in farming and primary agricultural production. A more widespread use of digital technologies in the food industry enterprises implies that more data is being generated downstream in the food supply chain. Generally, larger enterprises, and particularly multinational food and beverage companies, tend to generate more data and invest more in data analytics. Differences in data generation and use also concern individual food processing segments, as some of these are still more labour than technology intensive.

\section{A European Strategy for Data}

A European strategy for data was announced by the European Commission in February 2020. It forms part of a suite of EU strategies and actions aimed at establishing a digital single market and a striving data economy in accordance with European values, fundamental rights and rules. It was announced shortly after two key regulations on data entered into force in the EU - the General Data Protection Regulation (2018) and the regulation on a framework for the free flow of nonpersonal data in the European Union (2019). The aim of the strategy is "to create a single European data space - a genuine single market for data, open to data from across the world - where personal as well as non-personal data, including sensitive business data, are secure and businesses also have easy access to an almost infinite amount of high-quality industrial data, boosting growth and creating value, while minimising the human carbon and environmental footprint" (European Commission 2020a, pp. 4-5). It is assumed that data will flow freely within the EU and across sectors, in full respect and in accordance with the requirements of European rules 
on privacy, data protection and competition law. The strategy also requires the rules for access and use of data to be fair, practical and clear. To facilitate the use of data in the common sectoral data spaces and cross-sector data use, the Commission proposes strengthening the governance mechanisms at EU level and in the member states and prioritizing the interoperability requirements and standards within and across sectors. In this context the importance of the principles on findability accessibility, interoperability and reusability (FAIR) of data has been underlined.

The Commission based the strategy on four pillars that encompass several parallel and mutually reinforcing actions, specifically 1) the adoption of a cross-sectoral governance framework for data access and data use; 2) investments in data and strengthening Europe's capabilities and infrastructures for hosting, processing and using data, ensuring interoperability; 3 ) the reduction of potential power and market imbalances in the data value chain by enhancing the portability right for individuals, investing in skills and in small and medium-sized enterprises; and 4) the development of EU-wide data spaces in strategic sectors and domains of public interest. Sectors and domains listed in the strategy include manufacturing, the European Green Deal, mobility, health, finance, energy, agriculture, public administration and skills. At the same time, the Commission has not precluded launching additional common European data spaces in other sectors and areas. The Commission also stressed the importance of continuing the efforts towards the creation of the European Open Science Cloud (EOSC), the initiative announced in 2016 as part of the European Cloud Initiative. The EOSC is conceived as a data space for European researchers, innovators, companies and citizens, a trusted digital platform providing open and seamless access to research and scientific data, computing infrastructure, data analysis services and other resources. It is planned that the EOSC "will be connected and fully articulated with the sectoral data spaces" (European Commission 2020a, p. 33).

The strategy details key actions and measures to be undertaken in each of four proposed pillars, including a timetable for their adoption and implementation. The initial actions to facilitate safe and trustworthy data sharing and the establishment of common European data spaces started with the adoption of the proposal for data governance regulation. The proposal, issued in November 2020, creates a mechanism for re-using certain categories of protected public sector data, a trust-increasing notification regime for data sharing providers, a mechanism for individuals and companies to engage in data altruism for the common good and the European Data Innovation Board. Other legislative measures and actions foreseen for 2021 and 2022 include i.a. a proposal for a Data Act, the launch of the European cloud service marketplace, investment in a highimpact project on European data spaces and federated cloud infrastructures and a European framework for measuring data flows and assessing their economic 
value both within Europe and between Europe and the rest of the world. Equally important activities include the selection of relevant high-value data sets stored by the public sector (i.a. geospatial, environmental, meteorological) and opening them up in accordance with the Directive on Open Data and the re-use of publicsector information (in machine readable formats, via APIs, and free of charge).

\section{Conceptual Views and Implementation Ideas for the European Common Data Space in Agriculture}

In April 2019 the EU member states adopted a joint declaration in which the need to promote relevant platforms and databases enabling cross-border pooling and sharing of agricultural data between farmers and throughout the value chain was first clearly expressed at political level (Joint Declaration 2019). The 2020 data strategy includes a few paragraphs devoted to the common data space in agriculture. The planned data space is "to enhance the sustainability performance and competitiveness of the agricultural sector through the processing and analysis of production and other data, allowing for precise and tailored application of production approaches at farm level" (European Commission 2020a, p. 22). The goals and objectives specified in the data strategy therefore focus on farms and primary production. Other non-production oriented approaches at farm level are not explicitly referred to in the strategy. Such a framing may seem quite narrow, particularly in the light of multifunctional character of European agriculture. One should also note that there is no specific reference to agri-food sector and food supply-chain processes and operations, either upstream or downstream (except for mentioning supply-chain data among the data streams feeding into the future data space). Overall, the vision of the common data space in agriculture, as presented in the data strategy, is quite general and at the same time limited to production approaches. To some extent this reflects the tendency to see data-based agriculture mainly through the prism of precision agriculture and precision-farming techniques. On the other hand, however, the strategy assumes a cross-sectoral governance framework and interoperability of data sharing between individual data spaces. One might therefore expect that a fully integrated and interoperable agricultural data space will increase the availability of data products and services aimed at addressing different needs in the sector and in the food supply chain.

The general idea presented by the Commission is that the future data space could function as a neutral platform for sharing and pooling agricultural data, including both private and public data. But concrete methods or other details concerning implementation of the planned data space still have to be agreed on between the EU institutions, EU governments and other stakeholders. While 
discussing possible solutions, the strategy proposes taking account of existing approaches to agricultural data sharing, experiences gained with the EU code of conduct for sharing of agricultural data by the contractual agreement developed in 2018 and agricultural data repositories or agricultural data spaces in current use in the EU. Specifically, it is recommended to take stock of the market for digital farm products and services, existing data-sharing infrastructures and data accumulated within different spaces and platforms, including data produced as a result of research projects funded under the Horizon 2020 programme.

The major conceptual view put forward by the Commission is that a common European data space in agriculture could be a kind of a framework that would federate, distribute and aggregate existing and relevant data platforms (Expert Workshop 2020). Concerning the building blocks of the common data space in agriculture, the Commission indicated that these could encompass multiple platforms that currently operate as a support to agricultural production and farm management (commonly referred to as farm management information systems), data and applications from agricultural input providers (i.a. chemical and seed companies), data alliances, ecosystems and initiatives for sharing data in specific subsectors (sometimes referred to as embryonic data spaces) and open data (Figure 3).

Defining a set of effective interoperability mechanisms, both of a legal and technical nature, would be a key challenge in the process of integrating these elements into a common and federated database system. These mechanisms should allow for the exchange, sharing and using data from multiple data streams and sources, including proprietary data, European data and data from other regions of the world. In many instances, the inclusion of data in the common space will be based on a voluntary commitment and hence should take due account of different expectations, interests and concerns of potential contributors. It is unclear to what extent private-sector actors - farmers, agri-food companies and agricultural technology providers - will be willing to cooperate and share their data assets in the framework of the common data space with the public sector institutions and with other actors from the private sector. Typical collective action problems such as the free-rider dilemma may impede the process of pooling data or halt it at suboptimal level. One can expect that the implementation of the common data space in areas where agricultural data must be reported and delivered to audit and monitoring authorities may proceed more smoothly and quickly. The willingness to share other data may, however, be lower. Although network effects increase the value of data platforms, these effects and benefits may not be clearly understood by many data holders. At the same time, many actors are afraid of security and privacy risks, fear losing income based on their proprietary 


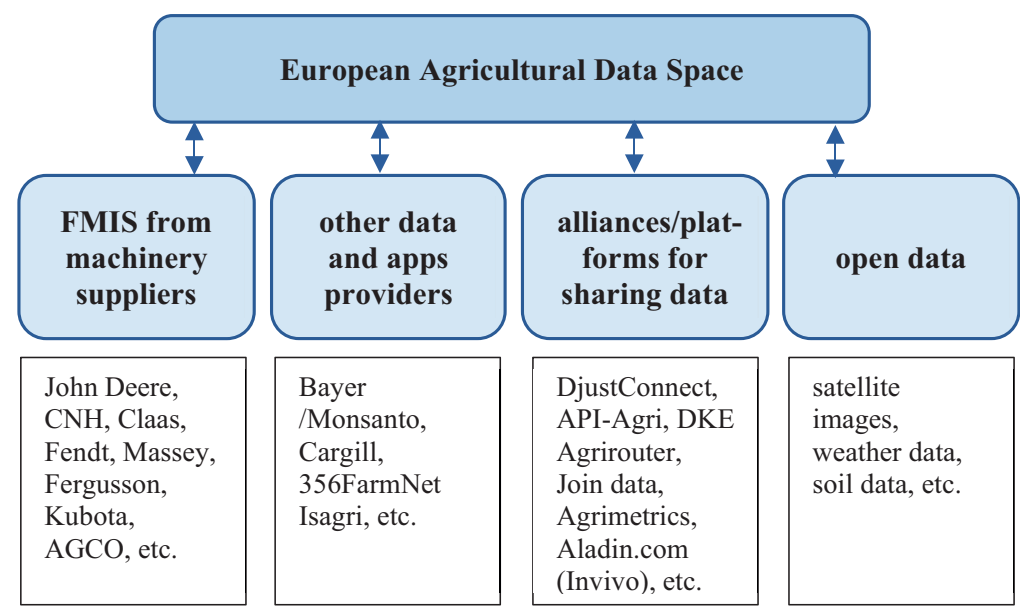

Figure 3. A conceptual view of European Agricultural Data Space

Rysunek 3. Koncepcyjna wizja Europejskiej Przestrzeni Danych Rolniczych

Source: Expert Workshop 2020.

Źródło: Expert Workshop 2020.

data or have concerns over their ability to maintain a competitive edge after sharing their data. It may also be difficult for some actors to determine which data are sensitive and which could serve public goods and be transferred or donated to the data pool (e.g. through the planned data altruism mechanism).

The funding for data spaces is to be provided under the Digital Europe Programme. While building the common data space, the Commission's intention is also to make use of projects on advanced digital technologies for agriculture and other data oriented projects and innovative actions funded by Horizon 2020. The EOSC, Open Science policies and other horizontal and cross-sectoral projects and initiatives mentioned are also expected to play a role in supporting the establishment of the data space in agriculture. These include, among others, the GAIA-X project, aimed at developing a federated data ecosystem based on European values, the International Data Space Association initiative for trusted data exchange across Europe and around the world, the TRUSTS project, aimed at creating a secure and trustworthy European data market for personal and industrial use and the EUHubs4Data, focused on creating a European catalogue of data sources and federated data-driven services and solutions for European SMEs, startups and web entrepreneurs. The Commission also plans to establish a European "Agriculture of Data" partnership under the Cluster 6 "Food, Bioeconomy, Natural Resources, Agriculture and Environment" of the new Horizon Europe 
research programme. The fundamental aim of the partnership will be to integrate and use environmental and Earth observation data to improve the sustainability performance of agriculture and the efficiency of policy monitoring and evaluation. These aims are also to be supported by the farm sustainability tool (FaST), a digital service platform developed by the European Commission in cooperation with member states' paying agencies for the CAP in 2020 and 2021. Both the FaST platform and the planned "Agriculture of Data" partnership have ambitions to provide space for combining environmental and Earth observation data with other public and private datasets, including user-generated data. Another important initiative of the Commission, formally announced in the Farm to Fork Strategy, concerns the conversion of the Farm Accountancy Data Network (FADN) into a Farm Sustainability Data Network (FSDN). It is planned to add more detailed environmental and social data to the current data sets in order to provide a more comprehensive picture of the situation of farms and their performance.

\section{The Common Data Space in Agriculture and Sustainability Issues}

The European Union attaches great importance to sustainability and actions aimed at addressing global problems of climate change, environmental degradation, biodiversity loss, food insecurity, poverty and social exclusion. All three pillars of sustainability - environmental, economic and social - are considered fundamental for economic growth and the long-term well-being of EU citizens. This EU approach has been fully embodied in the new European Green Deal strategy and the European Recovery Plan adopted in 2020 to overcome the negative consequences of the COVID-19 pandemic. With the aim of enhancing sustainability orientation, the European Commission has also developed the European Annual Sustainable Growth Strategy to provide guidelines for the economic and employment policy and other the EU measures and actions. Actions aimed at digitalisation and digital transformation in Europe are also expected to be designed in such a way as to not only avoid potential risks and problems, but also to broaden and deepen sustainability performance. The common data space in agriculture can be considered the backbone and major driver of digital transformation in the sector. Pooling agricultural data may improve agricultural production and help in the preservation and restoration of natural resources. At the same time, while acknowledging the fact that the common data space may create profound synergies between digitalisation and sustainability in the sector, one must also address some unintended impacts and loopholes that can undermine sustainability efforts and goals. The need for identifying potential conflicts between digitalisation and sustainability has been stressed in many scientific circles in recent years. Notably, the expert group 
of European scientists called for the development of guidelines for responsible use of digital data with the intention of limiting any unintended impacts of digital transformation (Scholz et al. 2018). Taking this into account, the following sections intend to discuss how and to what extent the common data space in agriculture could support environmental, economic and social sustainability.

\subsection{Environmental Sustainability}

As nature and biodiversity significantly contribute to economic growth and human welfare and health, fostering effective policies and actions for environmental sustainability remains fundamental (Dasgupta 2021). There is a growing conviction that in order to achieve the environmental dimension of sustainable development one has to go far beyond limiting the negative impacts of human activity on nature, and focus on the effective preservation and regeneration of natural resources. With the current state and scope of digitalisation in Europe and in European agriculture, the common data space would to a large extent rely on public environmental and Earth observation data and data collected on large farms using high-tech precision agriculture techniques. Hence one may wonder to what extent the use of the combination of these datasets might improve the sustainability performance in the sector, and particularly the regeneration of ecosystems and their services. There are divergent perspectives concerning the impact of precision agriculture technologies on environmental sustainability (Clapp and Ruder 2020). It has been found that the use of these technologies positively contributes to GHG emissions mitigation (Balafoutis et al. 2017). These effects are mainly due to more precise and hence reduced application of fertiliser, reduced fertiliser production and reduced fuel use (Soto et al. 2019). It is widely held that the larger the farm the greater the potential benefits from high-tech precision agriculture techniques - with the increasing size of the farm, investment costs per hectare fall and input use reductions and GHG reductions increase. On the other hand, there is also evidence that savings from the more efficient use of fertilisers, pesticides and fuel are quite modest. Data from German precision farms show that the savings identified so far are in the low single-digit percentage range (Beste 2021). At the same time, it should be remembered that although inputs may be used more efficiently, the technologies used in precision agriculture still fail to provide a comprehensive picture of complex interactions in natural systems (Idel and Beste 2020). In other words, data-based prescriptions for input use are primarily focused on maximising yields and production and to a much lesser extent on building soil and livestock health and resilience. Automatic recommendation systems are also most often limited to solving problems 
and improving outcomes in one area, which may not necessarily have the same positive impacts in other interdependent layers of farming ecosystems. One may therefore raise concerns over long-term environmental impacts of repeated optimisation techniques applied on the same fields to have maximum yields in each season (cf. Lajoie-O'Malley et al. 2020). Holistic and environmentally oriented precision agriculture techniques would require the full datafication of farms and farming ecosystems, which is still hard to achieve today.

These limits and problems have important consequences for the planned common data space in agriculture. Although the adoption rates of precision farming are still low and data from precision farms cannot be accessed and shared easily in the agricultural value chain, this is in fact the data that currently provides the bulk of private agricultural datasets. If obstacles to data sharing are overcome, such a supply-side situation implies that the common data space would become a hub for precision farming data. Pooling greater volumes of precision agriculture data would support knowledge generation and savings for high-tech precision farms potentially contributing to greater GHG reductions, however it would not suffice to preserve and to restore natural systems on which farming and food production depend. To fulfil the ambitions of the European Green Deal and related EU strategies the common data space in agriculture should primarily be focused on pooling private and public data relevant for organic, agroecological and regenerative farming practices. This requires a much greater scope of digitalisation in agriculture than exists today. Specifically, the use of digital technologies and data collection on different categories of farm, including agroecological and smaller units that do not use high-tech precision agriculture techniques, should be encouraged. A common data space including private farm data representative of different European farming systems and regions in Europe would be highly relevant for achieving environmental sustainability goals.

\subsection{Economic Sustainability}

Since access and use of data becomes a huge competitive advantage and source of growth for businesses, the common data space will have significant impacts on economic developments and relations in the food supply chain. Currently, agricultural data markets are dominated by a relatively small number of large corporations that control the markets for machines, seeds, fertilisers and pesticides (Clapp and Ruder 2020, p. 53). The business models of leading agricultural data aggregators are primarily focused on conventional and large-scale industrial farming systems that generate predictable revenue. A significant concentration of agricultural data and the data advantages of larger farms change the competition conditions 
in the sector and may also undermine the European model of agriculture. The fact that private agricultural data are now concentrated in a handful of companies negatively affects innovation and the prices of data-based products and services for farmers. It also raises concerns over increasing powers of corporations and their detailed knowledge of operation processes at farm level (Kritikos 2017, pp. 48-49). This is more particularly so as many of agricultural data controllers are located outside Europe. Pooling data in the common European data space could increase access to data for other businesses, including small and medium-sized companies and start-ups. This could boost innovations and increase the variety and quality of data applications and services for agriculture and food supply chain management.

However, a set of specific rules, principles and governance mechanisms for the common agricultural data space would be required to support economic sustainability in the agri-food sector. The International Data Space Association recently indicated and specified four cross-sectoral design principles for common data spaces, specifically data sovereignty, a data level-playing field, a decentralised soft infrastructure (meaning a set of data and system interoperability mechanisms and standards) and public-private governance (IDSA 2021). All these principles are equally important when it comes to supporting a more sustainable development of the emerging data economy in agriculture. At the same time, the data sovereignty principle may potentially be the most meaningful from farmers' perspective. It is a novel and innovative concept that describes the ability of data originators to take autonomous and sovereign decisions with regard to their economic data goods. Taking into account the current power imbalances and problems in agricultural value chain, the introduction of the data sovereignty principle into the EU legislative framework would empower farmers by acknowledging their autonomy and rights to freely determine how and by whom their farm data may be used. In many instances such a legal principle would provide for greater protection of farmers' interests than mere data ownership rights (Schönfeld, Heil and Bittner 2018, p. 115).

However, overcoming legal, technical and other barriers to agricultural data sharing in the EU will not remove the fundamental problems of the limited representativeness of current agri-food data assets in the EU. Some of these problems result from structural data disadvantages faced by some categories of farm. In such circumstances, enhancing access to and sharing of agricultural data by means of the common data space will enable a more innovative and data-driven agriculture, but it may also deepen divides between data-rich and data-poor farms. The utility of data-based products and services increases along with the volume of site-specific data accumulated in the farm. Data models for larger and digitally mature farms are likely to be more accurate and hence potentially more valuable economically than data models for smaller units and new entrants with no historical data records. 
With these differences, a new market for agricultural data may have differing impacts on agricultural productivity, agricultural prices and farm incomes. Hence compensation mechanisms for some farms may be required to support economic sustainability in the sector. However, such a subsidy scheme, potentially under the CAP, should go beyond mere income support and be designed in such a way as to support the collection and sharing of data important for enhancing the sustainability performance in the EU.

\subsection{Social Sustainability}

Fair data relations, inclusive digital policies and human-oriented approaches are fundamental when it comes to ensuring social sustainability in the agri-food sector witnessing a rapid shift to more digital and technology-based modes of work. Digitalisation and new technologies carry the risk of increasing inequalities and social exclusion - the problems that already represent a significant issue in the agri-food sector and in various rural regions in Europe. It would therefore be important to provide for conditions ensuring a more equitable deployment and use of digital technologies in the sector. This requires not only a better access to high-speed broadband networks, but also education policies and measures aimed at raising digital and data management skills among farmers and rural areas' inhabitants (Staboulis and Kostas 2020).

Data cooperatives created and managed by farmers themselves could play a positive role in strengthening the social foundations of digital transformation in farming. Data cooperation could empower farmers in relations with digital technology providers. It could also increase trust in the data value chain and hence facilitate data sharing in the sector. The acknowledgement of the importance of farmers' knowledge, expertise and experience would be equally important for a socially sustainable digital agriculture. Farmers as end-users of various databased tools, software and applications for digital agriculture should be engaged in designing their features and functionalities (Kernecker et al. 2020). Participatory approaches to developing digital tools generate important human-sourced data that would be also an important input in the common data space in the sector. Experience gained with the use of precision farming techniques and agricultural systems modelling indicate that machine-generated data and remote sensing data often do not suffice to understand and explain the complexity of interactions occurring at different levels of farming operations (cf. Antle 2019).

The common data space in agriculture should also cater for the needs, interests and the well-being of other actors in the food supply chain, including consumers, who will be paying for data-enhanced food products and services. Specifically, 
the common agricultural data space should facilitate building a food system that will support the planet, biodiversity, human health and the wider society. To a large extent, the achievement of these goals will be supported by high-value datasets held by the public sector, which will be open for re-use and sharing within the common data space. Nonetheless, private farm data are also badly needed to improve the prospects for achieving common social goals. Rapid changes towards the improvement of farming practices in conventional farming systems are required, thus the adoption of more precise and data-based techniques to limit the use of fertilisers and pesticides and to support more sustainable food production on conventional farms should be encouraged. Yet the effective support of social sustainability requires inclusive policies and governance structures that will encourage all groups of farmers (large, small, conventional, industrial, organic, regenerative and other) to share their data.

With this being said, it is important to note that types of data shared also matter. Fundamentally, data governance policies for the common data space in agriculture should take account of the fact that private agricultural data consists of datasets that differ in terms of their value for the public and broader social welfare. Agrienvironmental data, traceability data and data from organic and regenerative farms, for example, will potentially have a greater positive impact on human health, biodiversity and climate change mitigation than other types of data. However, given specific socio-economic constraints in the agri-food sector and observed digitalisation trends, such high-value private agricultural datasets tend to be undersupplied by the market.

\section{Conclusions}

The project of the single data market encompassing common data spaces in agriculture and in other sectors and areas is undoubtedly one of the most ambitious and progressive projects announced by the European Union in recent years. The ambitions of the EU institutions are that the future data spaces, including the agricultural data space, will support the achievement of long-term environmental, economic and social sustainability goals in the EU. However, the realisation of these goals remains challenging, particularly in the context of the rapid, but uneven pace of digital transformation. Removing various barriers to sharing the data in the common market is fundamental, but at the same time it is only one of many other actions and steps needed to improve the prospects for using data for achieving sustainable development goals. The agricultural data value chain is one of the most complex and problem-laden data value chains in the emerging digital economy. The scale of power imbalances and inequalities in the sector seem larger than in other sectors 
or industries. With the planned regulatory changes some of the most prominent problems in the agricultural data economy, and specifically data concentration, limited data interoperability, lack of trust in data aggregators and data intermediaries, may be overcome. The number of initiatives and activities for the standardisation of data formats and technical protocols for data transmission has substantially increased in the EU in recent years. In addition, large investments in digital competencies and information infrastructures in the agricultural sector are planned in the coming years. The increasing number of public-sector data initiatives may provide a counterweight to the hegemony of large digital companies on data markets. Yet more specific actions at sectoral level are needed, including interventions from the CAP or other policies to promote more responsible and inclusive data policies in the sector. Digitalisation in agriculture has become one of the most important aims of the CAP post 2020, but support measures and programmes for farmers are still detached from actual data production and use. It would also be recommended to elaborate on the link between the CAP and European Open Science Cloud.

The review of digitalisation processes in the agri-food sector shows that accumulated private agri-food data assets in Europe continue to be incomplete when it comes to representation of different farming systems, agricultural sectors and regions. Digitalisation has been generally more advanced in northern and western Europe and in the downstream segments of the agri-food supply chain. Yet significant gaps in data coverage can also be identified in these regions and segments. In an increasingly digital economy, persistent inequalities in private data production combined with limited access to data have to be considered as a negative development. More balanced agri-food data generation and use, and specifically data records collected internally by farms and enterprises of different sizes, types and locations are of fundamental importance for the effective support of sustainability. However, because of many social, economic and technological constraints, such diverse and heterogeneous agri-food data resources have not yet been built in Europe.

Deficiencies in data production and an immature data ecosystem in the agri-food sector require the design of the common data space in agriculture as well as the rules for data access and use to be carefully considered. The absence of well-designed rules and the lack of sector-specific interventions may result in increasing the range of data products and services primarily benefiting digital forerunners, high-income countries and large farms and agricultural holdings. There are currently no guidelines or rules that would indicate desired and undesired objectives and directions of data collection and usage in the agri-food sector. This leaves data aggregators and digital technology providers with a great deal of leeway in shaping digital transformation in the sector. One may doubt whether, in such a setting, agri-food datasets are 
being sufficiently used to meet environmental and other important social goals. Although direct payments, the major CAP support scheme, become increasingly dependent upon meeting environmental and climate goals, these mechanisms are not linked to the requirement to collect and share agri-environmental or other data. In an increasingly digital world where data is vital to economic growth and social well-being, establishing links between CAP support schemes and the emerging data economy in agriculture would be desirable. With a suitable regulatory framework, effective governance structures and specific sectoral support schemes the common agricultural data space is more likely to deliver on sustainability goals.

\section{References}

Antle J.M. (2019). Data, economics and computational agricultural science. American Journal of Agricultural Economics, 101 (2), 365-382. DOI:10.1093/ajae/aay103.

Balafoutis A., Beck B., Fountas S., Vangeyte J., Wal T.V.D., Soto I., Gómez-Barbero M., Barnes A., Eory V. (2017). Precision agriculture technologies positively contributing to GHG emissions mitigation, farm productivity and economics. Sustainability, 9 (8), 1339. DOI:10.3390/su9081339.

Beste A. (2021). Precision farming - or "The emperor's new clothes"? Agricultural and Rural Convention - ARC2020. https://www.arc2020.eu/precision-farming-or-the-emperors-new-clothes/ (access: 26 May 2021).

Burg S. van der, Oosterkamp E., Bogaardt M.J., Regan A., Tabeau-Kowalska E., Popa E., Wattel C., Brunori G., Favelli E. (2020). Futures of farm data sharing practices. Perspectives of European farmers, researchers and agri-tech businesses. Internet of Food and Farm 2020, Report D7.4. DOI:10.13140/RG.2.2.21562.41924.

Burg S. van der, Wiseman L., Krkeljas J. (2020). Trust in farm data sharing: Reflections on the EU code of conduct for agricultural data sharing. Ethics and Information Technology. DOI:10.1007/s10676-020-09543-1.

Clapp J., Ruder S.-L. (2020). Precision technologies for agriculture: Digital farming, geneedited crops, and the politics of sustainability. Global Environmental Politics, 20 (3), 49-69. DOI:10.1162/glep_a_00566.

Dasgupta P. (2021). The Economics of Biodiversity: The Dasgupta Review. London: HM Treasury.

European Commission (2020a). A European Strategy for Data: Communication from the Commission to the European Parliament, the Council, the European Economic and Social Committee and the Committee of the Regions. 19.2.2020, COM(2020) $66 \mathrm{fi}-$ nal. Brussels: European Commission.

European Commission (2020b). Digital Economy and Society Index (DESI) 2020. Thematic chapters (pp. 18-36). Brussels: European Commission.

Expert Workshop (2020). How to build a "Common European Agricultural Data Space", summarized in workshop report prepared by Faraldi M., Micheletti G. and Pepato C., 8.09.2020. Brussels. 
Gossé J., Hoffreumon Ch., Zeebroeck N. van (2020). European Enterprise Survey on the Use of Technologies Based on Artificial Intelligence. A Study Prepared for the European Commission. Luxembourg: Publications Office of the European Union. DOI:10.2759/759368.

Idel A., Beste A. (2020). The Myth of Climate Smart Agriculture - Why Less Bad Isn't Good. Commission by Martin Häusling MEP. Version updated in April 2020. https://gesunde-erde.net/media/myth_of_climate_smart_agriculture_final.pdf (access: 26 May 2021).

IDSA [International Data Space Association] (2021). Design principles for data spaces. Position paper - version 1.0. April. Dortmund: International Data Spaces Association.

Joint Declaration (2019). Declaration of cooperation on A smart and sustainable digital future for European agriculture and rural areas signed by 26 EU Member States on 5 April 2019 in Brussels.

Jouanjean M.-A., Casalini F., Wiseman L., Gray E. (2020). Issues around data governance in the digital transformation of agriculture: The farmers' perspective. OECD Food, Agriculture and Fisheries Papers, No. 146. Paris: OECD Publishing. DOI:10.1787/53ecf2ab-en.

Kernecker M., Knierim A., Wurbs A., Kraus T., Borges F. (2020). Experience versus expectation: Farmers' perceptions of smart farming technologies for cropping systems across Europe. Precision Agriculture, 21 (1). DOI:10.1007/s11119-019-09651-z.

Kritikos M. (2017). Precision Agriculture in Europe - Legal Social and Ethical Considerations. Brussels: European Parliamentary Research Service. DOI:10.2861/278.

Lajoie-O’Malley A., Bronson K., Burg S. van der, Klerkx L. (2020). The future(s) of digital agriculture and sustainable food systems: An analysis of high-level policy documents. Ecosystem Services, 45, 101183. DOI:10.1016/j.ecoser.2020.101183.

Nguyen D., Paczos M. (2020). Measuring the economic value of data and cross-border data flows - A business perspective. OECD Digital Economy Papers, No. 297. Paris: OECD Publishing. DOI:10.1787/6345995e-en.

Pedersen S.M., Lind K.M. (2017). Precision agriculture - From mapping to site-specific application. In: S.M. Pedersen, K.M. Lind (eds.). Precision Agriculture: Technology and Economic Perspectives (pp. 5-12). Cham: Springer.

Posadas B.B., Gilbert J.E. (2020). Regulating Big Data in agriculture. IEEE Technology and Society Magazine, September, 86-92. DOI:10.1109/MTS.2020.3012333.

Sadowski J. (2019). When data is capital: Datafication, accumulation, and extraction. Big Data \& Society, 6 (1), 1-12. DOI:10.1177/2053951718820549.

Scholz R.W., Bartelsman E.J., Diefenbach S., Franke L., Grunwald A., Helbing D. et al. (2018). Unintended side effects of the digital transition: European scientists' messages from a proposition-based expert round table. Sustainability, 10 (6), 2001. DOI:10.3390/ su10062001.

Schönfeld M.V., Heil R., Bittner L. (2018). Big data on a farm - Smart farming. In: T. Hoeren, B. Kolany-Raiser (eds.). Big Data in Context. Legal, Social, and Technological Insights (pp. 109-120). Cham: Springer.

Soto I., Barnes A., Balafoutis A., Beck B., Sánchez B., Vangeyte J., Fountas S., Van der Val T., Eory V., Gómez-Barbero M. (2019). The Contribution of Precision Agriculture Technologies 
Towards a Common Agricultural Data Space in the European Union...

to Farm Productivity and the Mitigation of Greenhouse Gas Emissions in the EU. Luxembourg: Publications Office of the European Union. DOI:10.2760/016263.

Staboulis M., Kostas A. (2020). The evolving nature of work in the agri-foodstuffs sector: The impact of precision agriculture and the necessity of acquiring new skills through lifelong learning. Social Cohesion and Development, 15 (1), 49-59. DOI:10.12681/ scad.25040.

Wiseman L., Sanderson J., Zhang A., Jakku E. (2019). Farmers and their data: An examination of farmers' reluctance to share their data through the lens of the laws impacting smart farming. NJAS - Wageningen Journal of Life Sciences, 90-91. DOI:10.1016/j. njas.2019.04.007.

\section{Na drodze do wspólnej przestrzeni danych dla rolnictwa w Unii Europejskiej. Perspektywa zrównoważonego rozwoju}

Streszczenie: W lutym 2020 r. Komisja Europejska ogłosiła nową strategię w zakresie danych, w której przedstawiła innowacyjną propozycję utworzenia jednolitej europejskiej przestrzeni dla danych, składającej się z wielu sektorowych wspólnych przestrzeni danych, w tym również w sektorze rolnictwa. Oczekuje się, że wspólna przestrzeń danych rolniczych zapewniać będzie wsparcie w procesie budowy inteligentnego, innowacyjnego i zrównoważonego systemu żywnościowego „od pola do stołu”. W oparciu o analizę ramowych warunków gromadzenia i udostępniania danych rolniczych w UE oraz inicjatyw Komisji w tym zakresie artykuł miał na celu omówienie, jak oraz w jakim stopniu wspólna przestrzeń danych rolniczych będzie służyć wspieraniu zrównoważonego rozwoju środowiskowego, gospodarczego i społecznego w UE. Stwierdzono, że realizacja celów zrównoważonego rozwoju za pomocą planowanej wspólnej przestrzeni danych pozostaje wyzwaniem, szczególnie w kontekście szybkiego, ale nierównomiernego tempa transformacji cyfrowej w sektorze rolno-spożywczym w UE. Przezwyciężenie prawnych, technicznych i innych barier w udostępnianiu danych w UE nie zlikwiduje podstawowego problemu, jakim jest ograniczona reprezentatywność obecnych zasobów danych rolniczych w UE. Dlatego też konstrukcja wspólnej przestrzeni danych w rolnictwie, a także zasady dostępu do nich i ich wykorzystywania, powinny być dokładnie przemyślane. Potrzebne byłyby również konkretne oraz powiązane $\mathrm{z}$ danymi środki interwencji, np. w ramach WPR, zarówno w celu zmniejszenia fragmentaryczności zasobów danych rolniczych w UE, jak i w odpowiedzi na rosnące potrzeby gromadzenia oraz udostępniania prywatnych danych rolniczych, które są kluczowe dla osiągnięcia szerszych celów społecznych i zrównoważonego rozwoju.

Słowa kluczowe: europejska strategia w zakresie danych, wspólna przestrzeń danych rolniczych, dane rolnicze, cyfryzacja, zrównoważony rozwój, zrównoważony system rolno-żywnościowy. 
